\title{
Improved Glycemic Control due to Reduction in Glucagon Levels by the Administration of Once-Weekly Dulaglutide in a Non-Obese Patient With Type 2 Diabetes
}

\author{
Shingo Morimitsu ${ }^{\mathrm{a}, \mathrm{c}}$, Hidetaka Hamasaki ${ }^{\mathrm{a}}$, b, c, d
}

\begin{abstract}
Treatment with glucagon-like peptide-1 receptor agonists (GLP1RAs) is a cornerstone for the management of obesity and type 2 diabetes. GLP-1RAs improve the glycemic control by suppressing glucagon secretion and stimulating insulin secretion in patients with type 2 diabetes. Here, we report the case of a patient with type 2 diabetes with postprandial hyperglucagonemia who was successfully treated by the administration of once-weekly dulaglutide. A 67-yearold, non-obese woman was admitted to our hospital for preoperative glycemic control. Her glycemic control significantly improved after the administration of dulaglutide. Both fasting and postprandial plasma glucagon levels were effectively suppressed by dulaglutide, which ameliorated hyperglycemia. Thus, to achieve an optimal glycemic control, clinicians should consider suppressing glucagon secretion in addition to improving insulin secretion and sensitivity.
\end{abstract}

Keywords: Type 2 diabetes; Glucagon-like peptide-1 receptor agonist; Glucagon

\section{Introduction}

Glucagon-like peptide-1 receptor agonists (GLP-1RAs) have been used for a decade and are recognized as cornerstones for the management of obesity and type 2 diabetes. A systematic review and meta-analysis have shown that a once-weekly treatment with dulaglutide reduced the hemoglobin A1c (HbAlc) level by $1.21 \%$ compared with that reduced by placebo [1]. Recently, a beneficial cardiovascular effect of GLP-1RAs has also become clear; cardiovascular and all-cause mortality was relatively decreased by approximately $10 \%$ in patients who underwent GLP-1RA treatment [2]. Mann et al [3] have shown

Manuscript submitted January 15, 2018, accepted January 30, 2018

aDepartment of Diabetes, Imakiire General Hospital, Kagoshima, Japan bHamasaki Clinic, Kagoshima, Japan

'SM and $\mathrm{HH}$ contributed equally to this work

${ }^{\mathrm{d}}$ Corresponding Author: Hidetaka Hamasaki, Hamasaki Clinic, 2-21-4 Nishi-

da, Kagoshima 890-0046, Japan. Email: hhamasaki78@gmail.com

doi: https://doi.org/10.14740/jem486w that liraglutide, which is a once-daily GLP-1RA, can prevent the progression of diabetic kidney disease and may also improve non-alcoholic fatty liver disease [4]. An adequate weight loss by the administration of GLP-1RAs may also lead to these beneficial effects. Generally, treatment with GLP-1RAs causes a weight loss of $3 \mathrm{~kg}$ in overweight or obese patients with or without type 2 diabetes [5]. However, the efficacy and safety of GLP-1RAs were equivalent in Asian patients with type 2 diabetes, regardless of their weight [6]. Thus, GLP-1RAs can be used for normal weight and obese patients with type 2 diabetes. Moreover, GLP-1 suppresses the glucagon secretion, which is supposed to be a major determinant of the glucose-lowering effect of GLP-1 action [7]. Here, we report the case of a patient with type 2 diabetes with postprandial hyperglucagonemia who was successfully treated with once-weekly dulaglutide.

\section{Case Report}

A 67-year-old woman was admitted to our hospital for pre-

Table 1. Characteristics of the Patient

\begin{tabular}{ll}
\hline Age $($ years $)$ & 67 \\
Height $(\mathrm{cm})$ & 156.2 \\
Weight $(\mathrm{kg})$ & 50 \\
BMI $\left(\mathrm{kg} / \mathrm{m}^{2}\right)$ & 20.5 \\
WC $(\mathrm{cm})$ & 82.5 \\
Duration of diabetes (years) & 15 \\
AST $(\mathrm{U} / \mathrm{L})$ & 55 \\
ALT $(\mathrm{U} / \mathrm{L})$ & 60 \\
BUN $(\mathrm{mg} / \mathrm{dL})$ & 7.3 \\
Cre $(\mathrm{mg} / \mathrm{dL})$ & 0.48 \\
eGFR $\left(\mathrm{ml} / \mathrm{min} / 1.73 \mathrm{~m}{ }^{2}\right)$ & 95.7 \\
Plasma glucose $(\mathrm{mg} / \mathrm{dL})$ & 206 \\
HbA1c $(\%)$ & 11.1 \\
GA $(\%)$ & 29.6 \\
U-ACR $(\mathrm{mg} / \mathrm{gCre})$ & 0 \\
\hline
\end{tabular}

BMI: body mass index; WC: waist circumference; AST: aspartate aminotransferase; ALT: alanine aminotransferase; BUN: blood urea nitrogen; Cre: creatinine; eGFR: estimated glomerular filtration rate; $\mathrm{HbA1c}$ : hemoglobin A1c; GA: glycoalbumin; U-ACR: urinary albumin creatinine ratio. 
$\mathbf{a}$
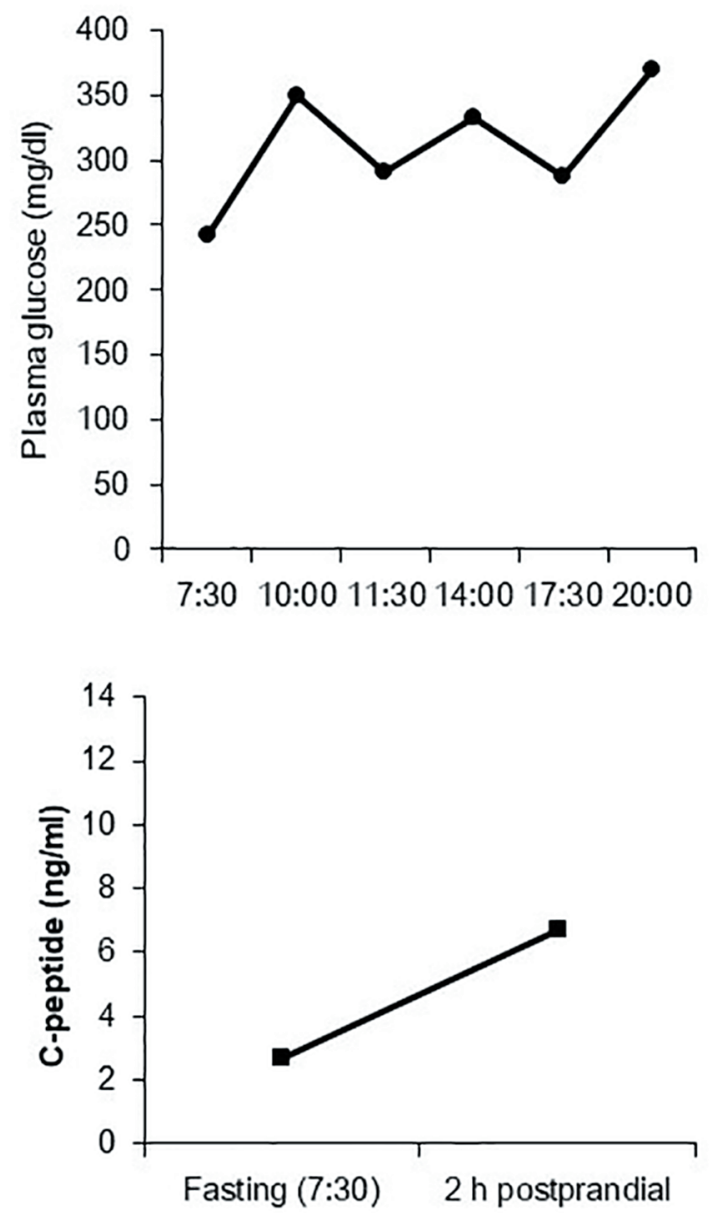

$(10: 00)$

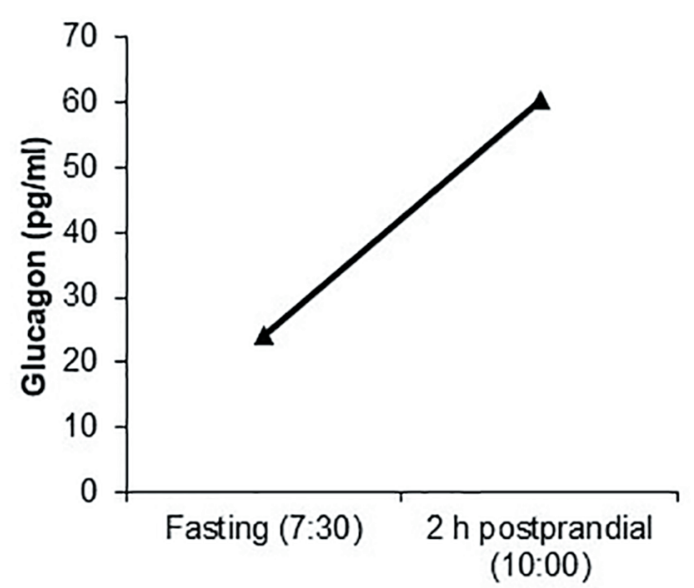

b
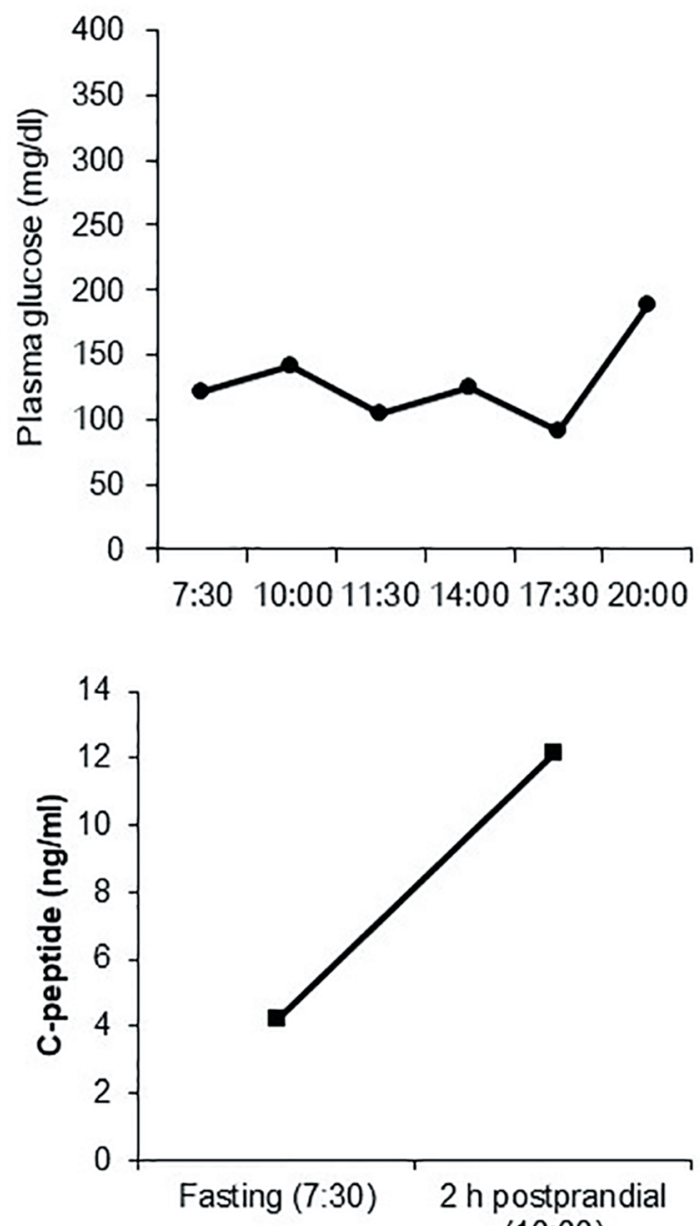

(10:00)

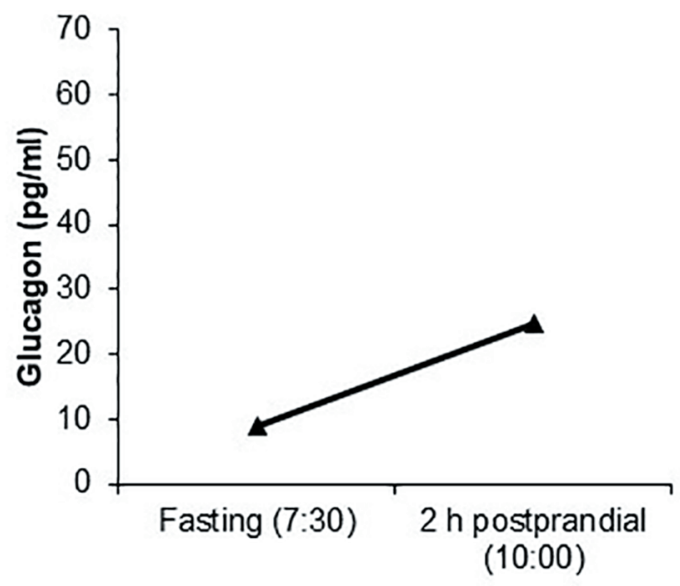

Figure 1. Daily plasma glucose profile as well as fasting and 2-h postprandial levels of C-peptide and glucagon before the administration of once-weekly dulaglutide (a) and after switching from vildagliptin to dulaglutide (b).

operative glycemic control. Her height, weight, and waist circumference were $156.2 \mathrm{~cm}, 50 \mathrm{~kg}$, and $82.5 \mathrm{~cm}$, respectively. Her anthropometric, demographic, and biochemical data are shown in Table 1 . She was diagnosed with type 2 diabetes 15 years ago and was treated with $500 \mathrm{mg}$ of metformin and 100 $\mathrm{mg}$ of vildagliptin. She also suffered from depression, and her dietary intake was unstable. On admission, her plasma glucose and $\mathrm{HbA} 1 \mathrm{c}$ levels were $206 \mathrm{mg} / \mathrm{dL}$ and $11.1 \%$, respectively. 
Diet therapy $(1,600 \mathrm{kcal} /$ day $)$ was started, which did not ameliorate her glycemic control. We added $500 \mathrm{mg}$ of metformin 5 days after admission; however, blood glucose levels remained at $200-300 \mathrm{mg} / \mathrm{dL}$. Her plasma glucose, serum C-peptide (Etest TOSOH II; Tosoh, Tokyo, Japan), and plasma glucagon (Glucagon ELISA; Cosmic, Tokyo, Japan) levels were measured before and $2 \mathrm{~h}$ after breakfast to investigate the $\alpha$ - and $\beta$-cell functions. Her endogenous insulin secretion was good, and postprandial glucagon secretion was elevated (Fig. 1a). We administered a once-weekly dulaglutide injection 8 days after admission, which ameliorated her glycemic control. She initially presented with nausea, which gradually disappeared. Her plasma glucose levels were $150 \mathrm{mg} / \mathrm{dL}$ (fasting), $238 \mathrm{mg} /$ $\mathrm{dL}$ ( $2 \mathrm{~h}$ after breakfast), $215 \mathrm{mg} / \mathrm{dL}$ (before lunch), $156 \mathrm{mg} / \mathrm{dL}$ ( $2 \mathrm{~h}$ after lunch), $117 \mathrm{mg} / \mathrm{dL}$ (before dinner), and $269 \mathrm{mg} / \mathrm{dL}$ ( $2 \mathrm{~h}$ after dinner). We added $0.75 \mathrm{mg}$ of repaglinide to improve the postprandial hyperglycemia. Before discharge, her plasma glucose levels had improved and were $122 \mathrm{mg} / \mathrm{dL}$ (fasting), $141 \mathrm{mg} / \mathrm{dL}$ ( $2 \mathrm{~h}$ after breakfast), $104 \mathrm{mg} / \mathrm{dL}$ (before lunch), 124 $\mathrm{mg} / \mathrm{dL}$ ( $2 \mathrm{~h}$ after lunch), $91 \mathrm{mg} / \mathrm{dL}$ (before dinner), and 189 $\mathrm{mg} / \mathrm{dL}$ ( $2 \mathrm{~h}$ after dinner). We also remeasured her serum $\mathrm{C}$ peptide and plasma glucagon levels before discharge (Fig. 1b) and found that both fasting and postprandial plasma glucagon levels were significantly decreased. The difference in plasma glucagon levels between fasting and 2-h postprandial state ( $\Delta$ Glucagon) was significantly decreased from 36.2 to 15.7 $\mathrm{pg} / \mathrm{mL}$ by the administration of dulaglutide, and that in serum C-peptide levels between fasting and 2-h postprandial state ( $\triangle \mathrm{CPR}$ ) was increased from 4.05 to $7.95 \mathrm{ng} / \mathrm{mL}$. However, the ratio of glucagon to $\mathrm{C}$-peptide was significantly decreased from $9.1 \times 10^{3}$ to $2.13 \times 10^{3}$ (fasting) and from $9 \times 10^{3}$ to 2.03 $\times 10^{3}$ (2-h postprandial), thereby suggesting that the suppression of glucagon secretion due to dulaglutide mainly contributed to the improved glycemic control.

\section{Discussion}

This case report shows that dulaglutide can effectively ameliorate glycemic control by reducing plasma glucagon levels in a non-obese patient with type 2 diabetes. We used a highly specific electrochemiluminescent sandwich immunoassay to measure plasma glucagon levels, which provided an accurate method for quantifying glucagon when compared with a previous radioimmunoassay [8]; thus, the results are highly reliable. Glucagon plays an important role in maintaining glucose homeostasis; however, it is abnormally secreted in patients with type 2 diabetes [9]. Clinicians have focused on insulin secretion and resistance/sensitivity during the treatment for type 2 diabetes; however, glucagon levels and variability should also be considered to achieve an optimal glycemic control. Hare et al [10] have reported that insulin secretion and glucagon suppression equally contribute to the glucose-lowering effect of GLP-1. Glucagon is a promising target for the treatment of type 2 diabetes. GLP-1RAs suppress glucagon secretion and promote insulin secretion and glucose uptake in muscles [11]. Considering this mechanism of action, although GLP1 RAs are usually used for obese patients with type 2 diabe- tes, these may also be effective for glycemic control in normal weight patients if no adverse effects occur. However, various unknown endocrine factors may also mediate glucose homeostasis. Recent studies have also suggested that GLP-2 plays a role in glucose metabolism and energy homeostasis [12, 13]. To elucidate the underlying mechanism, further research is required.

\section{Competing Interests}

The authors declare that they have no competing interests.

\section{References}

1. Htike ZZ, Zaccardi F, Papamargaritis D, Webb DR, Khunti K, Davies MJ. Efficacy and safety of glucagonlike peptide- 1 receptor agonists in type 2 diabetes: A systematic review and mixed-treatment comparison analysis. Diabetes Obes Metab. 2017;19(4):524-536.

2. Bethel MA, Patel RA, Merrill P, Lokhnygina Y, Buse JB, Mentz RJ, Pagidipati NJ, et al. Cardiovascular outcomes with glucagon-like peptide-1 receptor agonists in patients with type 2 diabetes: a meta-analysis. Lancet Diabetes Endocrinol. 2018;6(2):105-113.

3. Mann JFE, Orsted DD, Brown-Frandsen K, Marso SP, Poulter NR, Rasmussen S, Tornoe K, et al. Liraglutide and renal outcomes in type 2 diabetes. N Engl J Med. 2017;377(9):839-848.

4. Dong Y, Lv Q, Li S, Wu Y, Li L, Li J, Zhang F, et al. Efficacy and safety of glucagon-like peptide-1 receptor agonists in non-alcoholic fatty liver disease: A systematic review and meta-analysis. Clin Res Hepatol Gastroenterol. 2017;41(3):284-295.

5. Vilsboll T, Christensen M, Junker AE, Knop FK, Gluud LL. Effects of glucagon-like peptide-1 receptor agonists on weight loss: systematic review and meta-analyses of randomised controlled trials. BMJ. 2012;344:d7771.

6. Zhang F, Tang L, Zhang Y, Lu Q, Tong N. Glucagonlike peptide-1 mimetics, optimal for Asian type 2 diabetes patients with and without overweight/obesity: meta-analysis of randomized controlled trials. Sci Rep. 2017;7(1):15997.

7. Nicolaus M, Brodl J, Linke R, Woerle HJ, Goke B, Schirra J. Endogenous GLP-1 regulates postprandial glycemia in humans: relative contributions of insulin, glucagon, and gastric emptying. J Clin Endocrinol Metab. 2011;96(1):229-236.

8. Sloan JH, Siegel RW, Ivanova-Cox YT, Watson DE, Deeg MA, Konrad RJ. A novel high-sensitivity electrochemiluminescence (ECL) sandwich immunoassay for the specific quantitative measurement of plasma glucagon. Clin Biochem. 2012;45(18):1640-1644.

9. Jiang $\mathrm{G}$, Zhang BB. Glucagon and regulation of glucose metabolism. Am J Physiol Endocrinol Metab. 2003;284(4):E671-678.

10. Hare KJ, Vilsboll T, Asmar M, Deacon CF, Knop FK, Holst JJ. The glucagonostatic and insulinotropic effects 
of glucagon-like peptide 1 contribute equally to its glucose-lowering action. Diabetes. 2010;59(7):1765-1770.

11. Drucker DJ. The role of gut hormones in glucose homeostasis. J Clin Invest. 2007;117(1):24-32.

12. Lund A, Vilsboll T, Bagger JI, Holst JJ, Knop FK. The separate and combined impact of the intestinal hor- mones, GIP, GLP-1, and GLP-2, on glucagon secretion in type 2 diabetes. Am J Physiol Endocrinol Metab. 2011;300(6):E1038-1046.

13. Baldassano S, Amato A, Mule F. Influence of glucagon-like peptide 2 on energy homeostasis. Peptides. 2016;86:1-5. 